\title{
VAIKŲ ASTMOS VALDYMAS COVID-19 LAIKOTARPIU
}

\author{
Ieva Zarinskaite் $\dot{1}^{1}$ Rasa Saulyte் ${ }^{1}$, Jolanta Kudzyt $\dot{\mathbf{e}}^{2}$ \\ ${ }^{1}$ Lietuvos sveikatos mokslu universiteto Medicinos akademijos Medicinos fakultetas, \\ ${ }^{2}$ Lietuvos sveikatos mokslu universiteto ligoninè Kauno klinikos, Vaiku ligu klinika
}

Raktažodžiai: astma, COVID-19, pandemija, SARSCoV-2, vaikai.

\begin{abstract}
Santrauka
Vaikų astma yra labiausiai paplitusi lètinè vaikų kvèpavimo takų liga. Vaikų sergamumas šia liga siekia 8,4 procento. Tyrimo tikslas - atlikti 2019-2021 metais išspausdintų mokslinių šaltinių, nagrinėjančiu vaikų astmos COVID-19 laikotarpiu klinikinius ypatumus, sisteminę analizę ir apibendrinti ligos diagnostiką ir gydymą. Duomenys rinkti iš medicininių duomenų bazių PubMed, ScienceDirect, Medscape ir UpToDate. Atlikta 20192021 metais spausdintų mokslinių straipsnių anglų kalba, atitinkančių tyrimo temą, apžvalga ir analizè. Tyrimo rezultatai parodè, kad COVID-19 pandemijos metu pasikeitè ne tik astmos priepuolių dažnis, bet buvo pakeistas ir astmos valdymas - praktiškai visi ịprastiniai antrinès ir tretinès priežiūros patikrinimai atliekami nuotoliniu būdu, taikant telemediciną. Išvados. Buvimas namuose riboja vaikų fizinio aktyvumo galimybes, todèl silpsta pagrindiniai ir pagalbiniai kvejpavimo raumenys. Vaikų astmos gydymas COVID-19 laikotarpiu turètų atitikti naujausias gaires, o valdymas aprèpti rizikos veiksnių mažinimą, vaikų ir tẻvų mokymą, pakopinį medikamentinį gydymą ir astmos kontrolę.
\end{abstract}

\section{Ivadas}

Astma yra uždegiminė kvėpavimo takų liga, kuria serga apie 6,1 milijono vaikų (iki 18 metų) visame pasaulyje, o sergamumas nuolat didèja [1].Astma pasireiškia padidejjusiu bronchų reaktyvumu ị dirgiklius, kvėpavimo takų obstrukcija bei pasikartojančiais dusulio, kosulio, švilpimo, krūtinès veržimo epizodais. Vaikams dažniausiai nustatomas II tipo uždegimas, kuriam būdingas padidèjęs eozinofilų kiekis [2]. Ši liga lemia struktūrinius kvejpavimo takų pokyčius, didesni epitelio pralaidumą infekcijoms, tarp jų ir SARS-CoV-2 [3]. Sergantiems astma vaikams COVID-19 infekcija gali lemti sunkesnes komplikacijas bei prastesnę ligos prognozę [4]. Pastebeta, jog vaikai serga lengvesne COVID-19 forma, negu suaugusieji, todèl susirgus net ir sunkia kvejpavimo takų liga, daugumai vaikų intensyviosios priežiūros neprireikè. Manyta, jog koronavirusas padažnins astmos priepuolius, tačiau buvo nustatyta, jog skubių vizitų dèl astmos COVID-19 pandemijos metu sumažejo net 76 procentais [5].

Tyrimo tikslas - atlikti 2019-2021 metais paskelbtų mokslinių straipsnių, nagrinejjančių vaikų astmos COVID-19 laikotarpiu klinikinius ypatumus, sisteminę analizę ir apibendrinti ligos diagnostiką ir gydymą.

\section{Tyrimo objektas ir metodika}

Atlikta mokslinès literatūros apžvalga. Duomenys rinkti iš kompiuterinių bibliografinių medicininių duomenų bazių PubMed, ScienceDirect, Medscape ir UpToDate. Paieška buvo vykdoma naudojant reikšminius žodžius: children asthma, COVID-19, SARS-CoV-2, pandemic, children. Apžvalgai naudoti 2019-2021 metais spausdinti straipsniai anglų kalba, atitinkantys tyrimo temą.

\section{Tyrimo rezultatai}

COVID-19 rizika vaikų astmos kontrolei. Astma tai lètinè liga, išskirtinai jautri COVID-19 sukeltiems pokyčiams. Netikèti aplinkos, medicinos praktikos ir vaistų vartojimo pokyčiai pakeitè astmos valdymą [1].

Aplinkos pokyčiai. Dèl karantino vaikai mokosi namuose nuotoliniu būdu. Tai mažina virusų, galinčių sukelti viršutinių kvejpavimo takų ligas arba astmos paūmèjimą tarp moksleivių, plitimą. Buvimas namuose riboja vaikų fizinio aktyvumo galimybes, todèl silpsta pagrindiniai ir pagalbiniai kvẻpavimo raumenys, kvėpavimas darosi paviršutiniškas, blogejja dujų apykaita. Vaikai namuose dažniau patiria namų alergenų, tokių kaip tabako dūmai, namų dulkių erkutès, pelèsių sporos, poveikị [6].

Medicininè priežiūra. Sveikatos priežiūros paslaugų pokyčiai COVID-19 pandemijos metu smarkiai pakeite astmos valdymą ir kontrolę. Daugelis klinikų riboja apsilankymus, skatina pacientus registruotis nuotolinèms konsultacijoms, kurias vykdo telekomunikacijų pagalba. Tai mažina vaikų riziką užsikrèsti SARS-CoV-2 infekcija, tačiau sveikatos 
priežiūros specialistai baiminasi dèl tinkamos vaikų astmos kontrolès namuose ir dažnesnès paūmèjimo galimybès [7].

Vaistu vartojimas. Atliktas tyrimas parodè, jog pandemijos laikotarpiu dèl tèvų baimès padidèjo vaistų vartojimas astma sergantiems vaikams. Tai gali turèti teigiamos itakos ligos kontrolei, tačiau vaistų, ypač kortikosteroidų, perdozavimas gali sulètinti viruso klirensą.

Diagnostikos iššūkiai pandemijos laikotarpiu. Pandemijos metu kyla sunkumų kliniškai diferencijuoti COVID-19 ligą vaikams ir astmos paūmėjimą, nes klinika, įskaitant sausą kosuli ir dusuli, yra panaši. Tinkamai astmos diagnostikai kliūčių kelia spirometrijos tyrimų ribojimas pandemijos metu. Spirometrijos metu matuojant oro tūrị bei greitị, galimas didesnis viruso plitimas tarp pacientų ir sveikatos priežiūros darbuotojų, todèl šis tyrimas atliekamas tik retais atvejais, kuomet spirometrijos duomenys yra būtini spręsti dèl gydymo [8].

Gydymo rekomendacijos COVID-19 laikotarpiu. Sveikatos priežiūros paslaugų pokyčiai per COVID-19 pandemiją smarkiai paveikè astmos valdymą ir kontrolę. Dèl karantino bei ekstremalios situacijos, siekiant kontroliuoti ligonių srautus, buvo stabdomi apsilankymai poliklinikose, sumažejjo teikiamų medicinos paslaugų, profilaktinių patikrinimų ir prevencinių programų vykdymas [9]. Nors vis dar diskutuojama, ar astma yra didelis COVID-19 ligos rizikos veiksnys, svarbu vykdyti gerą astmos kontrolę, nes nekontroliuojama astma galètų sukelti sunkesnę COVID-19 ligos eigą. Keliuose tyrimuose buvo nustatyta, jog astma sergantiems vaikams ir suaugusiesiems yra didesnè intubacijos ir dirbtinés plaučių ventiliacijos (DPV) rizika [10]. Nors bendras COVID-19 sergančių vaikų hospitalizavimo dažnis, lyginant su suaugusiaisiais, yra mažas (8 iš 100 000), tačiau kas trečias hospitalizuotas vaikas patenka ị intensyviosios terapijos skyrių. Ekspertų grupès teigia, jog reikia dèti visas pastangas, kad būtu išvengta SARS-CoV-2 viruso poveikio ir kad visi nuolat vartojami vaistai, reikalingi astmos kontrolei, iskaitant inhaliacinius, geriamuosius gliukokortikoidus ir monokloninius antikūnus (omalizumabą, mepolizumabą) COVID-19 pandemijos metu būtų vartojami ir toliau [11,12]. Gera astmos kontrolè mažina astmos paūmèjimo riziką. Nèra patikimų ịrodymų, kad ịkvepiami gliukokortikoidai ar monokloniniai antikūnai turètų neigiamą poveikị COVID-19 infekcijos eigai $[13,14]$. Reikia laikytis ịprastų rekomendacijų vartoti sisteminius gliukokortikoidus astmos paūmèjimo metu, nes, atidejjus gydymą, gali padidèti gyvybei pavojingo paūmèjimo rizika [15].

Astmos valdymas apima simptomų kontrolę, vaikų ir jų tèvų mokymą, rizikos veiksnių mažinimą, medikamentinị ir nemedikamentinị gydymą. Vienas svarbiausių astmos kontrolès optimizavimo komponentų yra ịtraukti pacientus ir jų artimuosius (šiuo atveju vaikų tèvus) ị mokymo procesą. Pacientų ir jų artimųjų švietimas mažina astmos paūmèjimo ir hospitalizavimo riziką, gerina kasdienę veiklą [16,17]. Ne mažiau svarbus astmą provokuojančių veiksnių identifikavimas ir šalinimas. Svarbu išsiaiškinti provokacinius veiksnius: namų ir išorinès aplinkos alergenus, vaistus, maisto alergenus bei nespecifinius veiksnius, tokius kaip tabako dūmai (pasyvusis rūkymas) ar emocinis stresas mokykloje [18].

Medikamentinis gydymas. Greta sunkios situacijos, kurią sukelia COVID-19 liga, pavasarị astma paūmejja daugeliui pacientų dèl padidejusio sezoninių alergenų kiekio bei atsiradusių kitų kvėpavimo takų virusų. Europos ligų prevencijos ir kontrolès centras (ECDC) rekomenduoja COVID - 19 pandemijos metu vartoti iprastinius vaistus astmos kontrolei palaikyti, kad būtų išvengta paūmèjimo [19]. Rekomenduojama skirti inhaliacinius kortikosteroidus kartu su montelukastu. Būtina ir toliau vengti astmą provokuojančių veiksnių, dažnai plauti rankas, laikytis fizinio atstumo, reguliariai prižiūrèti inhaliatorius ir tarpines. Astmos kontrolè svarbi išvengti jos paūmèjimo, kad vaikams, patekusiems ị sveikatos priežiūros įstaigą, nepadidètų rizika užsikrėsti COVID-19 liga. Pandemijos metu svarbu srovini purkštuvą pakeisti dozuotu purškiamuoju arba sausujų miltelių inhaliatoriumi, nes srovinio purkštuvo naudojimas didina riziką virusui nusèsti apatinėse plaučių dalyse. Naudojant srovinị purkštuvą, skatinamas kosulio refleksas, kurio metu gali padidèti infekcijos perdavimo rizika. Vienintelès galimos priežastys, del kurių vaikas gali naudoti srovini pukštuvą pandemijos metu, yra blogas ligos atsakas ị dozuotą purškiamaji ar sausujų miltelių inhaliatorių [20].

N. Papadopoulos ir kt. [21] atliko kohortini tyrimą, kuriame dalyvavo1054 astma sergantys ir 505 sveiki vaikai iš penkiolikos šalių. Buvo nustatyta, jog pandemijos metu astma sergantys vaikai rečiau sirgo viršutinių kvẻpavimo takų infekcijomis, buvo rečiau hospitalizuojami ị sveikatos priežiūros ịstaigas dèl astmos priepuolių. Vaikams, sergantiems astma, pandemijos metu buvo nustatytas mažesnis viršutinių kvẻpavimo takų infekcijų dažnis, lyginant su 2019 metais (atitinkamai 30,9 proc. ir 81,6 proc, $\mathrm{p}<0.001$ ). Pandemijos metu vaikai rečiau sirgo apatinių kvẻpavimo takų infekcijomis, rečiau karščiavo, sumažèjo ūmių astmos priepuolių ir hospitalizacijų skaičius, lyginant su 2019 metais (atitinkamai 1,2 proc. ir 9,8 proc., $\mathrm{p}<0.001$ ).Sergančių vaikų astmos kontrolè pagerejjo net 33 proc., o šis pagerejjimas siejamas su geresne provokuojančių veiksnių prevencija, socialiniu atsiribojimu bei nuoseklesniu gydymo režimo laikymusi. Vis dèlto sumažejęs ūmių astmos epizodų dažnis nepatvirtina, jog astma gali būti COVID-19 ligos rizikos veiksnys. Kitu autorių atlikto tyrimo duomenimis [8] gauti panašūs rezultatai - nustatyta, jog hospitalizavimo atvejų skaičius žymiai 
sumažèjo pandemijos metu. Tyrimas parodè, jog sezoniniai koronavirusai rečiau sukelia astmos paūmèjimus, lyginant su kitais virusais, tokiais kaip gripo ar rinovirusai. Be to, astma sergantys vaikai gali būti apsaugoti nuo SARS-CoV-2 infekcijos dèl sumažejusio angiotenziną konvertuojančio fermento 2 (AKF2) receptorių kiekio, reikalingų koronavirusų atpažinimui ir infekcijos plitimui [22, 23].

Nemedikamentinis gydymas. Vienas svarbiausių nemedikamentinių gydymo būdų yra provokuojančių veiksnių mažinimas [24]. Tẻvai turètų nerūkyti, kiek įmanoma vengti dulkių, alergizuojančiu gyvūnų namuose bei šalto oro. Apsaugoti vaikus nuo jiems per didelio fizinio krūvio ar emocinio streso. Astma sergančio vaiko kambarys turi būti kasdien védinamas $[25,26]$.

Alergenu specifine imunoterapija (SIT). Specifinè imunoterapija skiriama viena iš dviejų šių vaistų formų: poodinė (leidžiama) arba poliežuvinè (lašinama, purškiama ar kitokia forma duodama vartoti per burną). Atlikto tyrimo metu nustatyta, jog sergančių astma vaikų poodiné imunoterapija parodè geresnius rezultatus nei poliežuvinè. Taikant poodinę imunoterapiją, sumažèjo įsijautrinimas alergenams bei poreikis ilgą laiką vartoti medikamentus [27,28].

\section{Išvados}

1. Vaikų astmos valdymas turètų apimti rizikos veiksnių mažinimą, vaikų ir tévų mokymą, pakopinị medikamentinị gydymą ir astmos kontrolès palaikymą.

2. Pandemijos metu kyla sunkumų kliniškai diferencijuoti COVID-19 ligą vaikams ir astmos paūmèjimą, nes klinika, îskaitant sausą kosulị ir dusulị, yra panaši.

3. Dèl karantino bei ekstremalios situacijos, siekiant kontroliuoti ligonių srautus, buvo stabdomi apsilankymai poliklinikose, sumažèjo teikiamų medicinos paslaugų, profilaktinių tikrinimų ir prevencinių programų vykdymas.

4. Buvimas namuose riboja vaikų fizinio aktyvumo galimybes, todèl silpsta pagrindiniai ir pagalbiniai kvèpavimo raumenys.

5. Vaistų vartojimas pandemijos laikotarpiu padidèjo tarp vaikų, sergančių astma.

6. Pandemijos metu astma sergantys vaikai rečiau sirgo viršutinių kvẻpavimo takų infekcijomis, buvo rečiau hospitalizuojami ị sveikatos priežiūros ịstaigas dèl astmos priepuolių.

7. Sezoniniai koronavirusai rečiau sukelia astmos paūmejjimus, lyginant su kitais virusais, tokiais kaip gripo ar rinovirusai.

\section{Literatūra}

1. Stern J, Pier J, Litonjua AA. Asthma epidemiology and risk factors. Semin Immunopathol 2020;42(1):5-15. https://doi.org/10.1007/s00281-020-00785-1

2. Gupta A, Ikeda M, Geng B, et al. Long-term safety and pharmacodynamics of mepolizumab in children with severe asthma with an eosinophilic phenotype. J Allergy Clin Immunol 2019;144(5):1336-1342.e7.

https://doi.org/10.1016/j.jaci.2019.08.005

3. Lee SC, Son KJ, Han CH, et al. Impact of comorbid asthma on severity of coronavirus disease (COVID-19). Sci Rep 2020;10(1):21805.

https://doi.org/10.1038/s41598-020-77791-8

4. Garg S, Kim L, Whitaker M. Hospitalization rates and characteristics of patients hospitalized with laboratory-confirmed coronavirus disease 2019 - COVID-NET, 14 states, March 1-30, 2020. MMWR Morb Mortal Wkly Rep 2020;69(15):458-64. https://doi.org/10.15585/mmwr.mm6915e3

5. Gupta A, Bush A, Nagakumar P. Asthma in children during the COVID-19 pandemic: lessons from lockdown and future directions for management. Lancet Respir Med 2020;8(11):10701071. https://doi.org/10.1016/S2213-2600(20)30278-2

6. Castro-Rodriguez JA, Forno E. Asthma and COVID-19 in children: a systematic review and call for data. Pediatr Pulmonol 2020;55(9):2412-2418.

https://doi.org/10.1002/ppul.24909

7. Abrams EM, Szefler SJ. Managing asthma during coronavirus disease-2019: an example for other chronic conditions in children and adolescents. J Pediatr 2020;222:221-226.

8. Abrams EM, Sinha I, Fernandes RM, Hawcutt DB. Pediatric asthma and COVID-19: the known, the unknown, and the controversial. Pediatr Pulmonol 2020;55(12):3573-3578.

https://doi.org/10.1002/ppul.25117

9. Oreskovic NM, Kinane TB, Aryee E, et al. The unexpected risks of COVID-19 on asthma control in children. J Allergy Clin Immunol Pract 2020;8(8):2489-2491.

10. Mahdavinia M, Foster KJ, Jauregui E, et al. Asthma prolongs intubation in COVID-19. J Allergy Clin Immunol Pract 2020;8(7):2388. https://doi.org/10.1016/j.jaip.2020.05.006

11. Global Initiative for Asthma (GINA). Global strategy for asthma management and prevention. 2021. www.ginasthma.org

12. Centers for Disease Control and Prevention. Coronavirus disease 2019 (COVID-19): people with moderate to severe asthma. https://www.cdc.gov/coronavirus/2019-ncov/need-extraprecautions/asthma.html

13. Chhiba KD, Patel GB, Vu THT, et al. Prevalence and characterization of asthma in hospitalized and nonhospitalized patients with COVID-19. J Allergy Clin Immunol 2020 146(2):307314.e4.

https://doi.org/10.1016/j.jaci.2020.06.010

14. Akenroye AT, Wood R, Keet C. Asthma, biologics, corticosteroids, and coronavirus disease 2019. Ann Allergy Asthma 
Immunol 2020;125(1):12-13.

https://doi.org/10.1016/j.anai.2020.05.001

15. Beaney T, Salman D, Samee T, Mak V. Assessment and management of adults with asthma during the Covid-19 pandemic. BMJ 2020;369:m2092.

https://doi.org/10.1136/bmj.m2092

16. Wang L, Timmer S, Rosenman K. Assessment of a university-based outpatient asthma education program for children. J Pediatr Health Care 2020;34(2):128-135. https://doi.org/10.1016/j.pedhc.2019.09.004

17. Lee C, Alexander E, Lee R, et al. Behavioral interventions for asthma self-management in South Asian populations: a systematic review. J Asthma. 2021;58(1):112-120.

https://doi.org/10.1080/02770903.2019.1658209

18. Kansen HM, Le TM, Meijer Y, et al. Perceived triggers of asthma impair quality of life in children with asthma. Clin Exp Allergy 2019;49(7):980-989.

https://doi.org/10.1111/cea.13407

19. Shaker MS, Oppenheimer J, Grayson M, et al. COVID-19: pandemic contingency planning for the allergy and immunology clinic. J Allergy Clin Immunol Pract 2020;8(5):1477-1488.e5. https://doi.org/10.1016/j.jaip.2020.03.012

20. Federico MJ, McFarlane AE 2nd, Szefler SJ, Abrams EM. The impact of social determinants of health on children with asthma. J Allergy Clin Immunol Pract 2020;8(6):1808-1814. https://doi.org/10.1016/j.jaip.2020.03.028

21. Papadopoulos NG, Mathioudakis AG, Custovic A, et al. Childhood asthma outcomes during the COVID-19 pandemic: findings from the PeARL multinational cohort. Allergy 2021:10.1111/all.14787. https://doi.org/10.1111/all.14787

22. Kuhn JH, Li W, Choe H, Farzan M. Angiotensin-converting enzyme 2: a functional receptor for SARS coronavirus. Cell Mol Life Sci 2004;61(21):2738-43. https://doi.org/10.1007/s00018-004-4242-5

23. Al Yazidi LS, Al Maskari N, Al Reesi M. Children with asthma hospitalised with COVID-19: multicentre experience. J Paediatr Child Health 2021;57(3):464-466.

https://doi.org/10.1111/jpc.15415

24. CDC COVID-19 Response Team. Coronavirus Disease 2019 in
Children - United States, February 12-April 2, 2020. MMWR Morb Mortal Wkly Rep 2020;69(14):422-426.

https://doi.org/10.15585/mmwr.mm6914e4

25. Isik E, Fredland NM, Freysteinson WM. School and community-based nurse-led asthma interventions for school-aged children and their parents: a systematic literature review. J Pediatr Nurs 2019;44:107-114. https://doi.org/10.1016/j.pedn.2018.11.007

26. Diorio C, Henrickson SE, Vella LA, McNerney KO, et al. Multisystem inflammatory syndrome in children and COVID-19 are distinct presentations of SARS-CoV-2. J Clin Invest 2020;130(11):5967-5975.

https://doi.org/10.1172/JCI140970

27. Pfaar O, Agache I, de Blay F, et al. Perspectives in allergen immunotherapy: 2019 and beyond. Allergy 2019;74 Suppl 108:3-25. https://doi.org/10.1111/all.14077

28. Novakova P, Tiotiu A, Baiardini I, et al. Allergen immunotherapy in asthma: current evidence. J Asthma 2021;58(2):223-230. https://doi.org/10.1080/02770903.2019.1684517

\section{MANAGEMENT OF PEDIATRIC ASTHMA DURING THE COVID-19}

\section{Zarinskaitė, R. Saulytė, J. Kudzytė}

Keywords: asthma, COVID-19, pandemic, SARS-CoV-2, children.

Summary

Pediatric asthma is the most common chronic childhood disease, with anincidence of $8.4 \%$ among children. Treatment of pediatric asthma during COVID-19 should be in line with the latest guidelines. Management of pediatric asthma should include risk reduction, parental training, tiered medication, and support for asthma control. It was not just the frequency of asthma attacks that changed during the COVID-19 pandemic, but management of asthma has also changed - almost all routine secondary and tertiary surveillance inspections were performed remotely using telemedicine.

Correspondence to: rassa.saulyte@gmail.com

Gauta 2021-04-30 